\title{
Social Work of the Future: Motives and Expectations among Social Work Students in Sweden
}

\author{
Pernilla, S. Liedgren ${ }^{1} \&$ Gudrun, V. Elvhage ${ }^{1,2}$ \\ ${ }^{1}$ The Academy of Health and Welfare, Department of Social Work, Dalarna University, Falun, Sweden \\ ${ }^{2}$ Department of Social Work, Stockholm University, Stockholm, Sweden. \\ Correspondence: Pernilla Liedgren, Health and Welfare, Dalarna University, Falun, Sweden.
}

Received: September 11, 2015

Accepted: September 25, 2015

Available online: October 13, 2015

doi:10.11114/ijsss.v3i6.1139

URL: http://dx.doi.org/10.11114/ijsss.v3i6.1139

\begin{abstract}
Is it possible to see future social work in today's social work students? It is likely that the way these students think about social work will form the future practice. In this study we investigate social work students' motives and expectations of their future profession. A survey was conducted among first semester students at four different universities in Sweden ( $\mathrm{n}=243)$. The survey asked questions about the students' motives, what they thought the main aim of social work is, and how they would like to be seen as social workers. The results show among other things that social work students consider the main aim of social work is to improve people's lives, advocate on people's behalf, and protect vulnerable people. The most frequently stated motives for becoming involved in social work were to help vulnerable people, and an interest in social issues, and the least important were religious or political reasons. The study has not being able to identify any future changes in social work. This could be interpreted as showing that social work has basic values that are constant over time and cultures.
\end{abstract}

Keywords: Social work student, motive, expectation, Sweden

\section{Introduction}

In many ways, social work and the social work profession is a result of the society it exists within. The motives and expectations of the social work profession are formed by education (Oyston, 2003), society (Payne, 2005; Healy, 2008) as well as students' own experiences and values (Perry, 2003). Social work programs have, over the years, been scrutinized in different reviews by the Swedish National Agency for Higher Education/Swedish Council for Higher Education, and they have been criticized for not being scholarly enough. As a result, the program has changed and has become more theoretical. Furthermore, a discussion of evidence-based practice within social work has been initiated, mainly through the National Board of Health and Welfare. The evidence-based practice discussion, together with the above mentioned changes, has not produced research-minded practitioners but at least has resulted in an awareness of what research could add to social work. This of course affects the perception of the social worker as someone who is slightly more systematic, organized, theoretical, bureaucratic, and research-minded, a bit from the 1970s politically, altruistic and an engaged idealist. However, it is possible to look at the situation from another angle. With a more existentialistic perspective it is viable to view social workers as agents, who are able to change social work practice by their own will. The aim in social work is to achieve change, and why should that not also include social workers and social work as a phenomenon? In other words, in this article we are working from the premise that influence does not flow just in one direction. Social work students' own motives and expectations ought to influence tomorrow's social work. By investigating students' motives and expectations we hope to get a glimpse of future social work. Studying the motives of social work students in their first semester would teach us what we can expect from social work in the future.

The aim of this article is to investigate the social workers of tomorrow by finding out social work students' motives for becoming social workers as well as what kind of social worker they would like to be. Furthermore, we are interested in whether there are any gender differences.

\section{Area descriptions: Motivations to become a social worker}

Previous studies have stated altruism to be the strongest or the first motive given by social work students when 
answering questions on why they study social work (Facchini \& Giraldo, 2013; Osteen, 2011; Hackett, Kuronen, Matthies \& Kresal 2003; Giurgiu \& Marica, 2013; Steven et al. 2010; Bradley et al, 2013). Besides altruistic motives, which could be verbalized as; "to have a job that achieves something", "helping others", "to make a positive contribution to society", "wanting to do something important, do something good", "wanted to help people", "help overcome discrimination", "to be of service to others", "a dedication to social justice", other motives that could be perceived as more individualistic have been discerned; some students are also attracted to study social work due to the possibility to get a stable job (Facchini \& Giraldo, 2013; Hackett et al, 2003), have a career (Stevens et al, 2013; Christie, 2006; Christie \& Kruk, 1998), express creativity (Giurgiu \& Marica, 2013), because of teaching modes offered by the program (Facchini \& Giraldo, 2013) or due to lifestyle issues (Bradley et al., 2012; Stevens et al, 2013).

Little importance is attached by students to acknowledgment, aesthetic aspects or roles as supervisors/controllers (Giurgiu \& Marica, 2013). Concerns with how they will be able to handle stress, workload, responsibility, own abilities, personal safety and bureaucracy are also expressed by students (Christie \& Kruk, 1998; Urbonienè, 2005).

It seems as if a low salary is something that is of less importance to social work students (Facchini \& Giraldo, 2013; Stoesz, Karger \& Carrilio, 2010). Having said this, the social work professionals are not averse to making money or receiving acknowledgement when these are possible. Students on a Master's of Social Work (MSW) course in the US state they study to get a license, be able to get into private practice earn more money (D'Aprix et al., 2004). Moreover, a study on Italian and Swedish students (Fortunato, Dellgran, \& Höjer, 2007) revealed that students' aspirations are often to become a psychotherapist, or to work therapeutically, for instance as a school counsellor. These are professions they regard as the most desirable and as offering the highest status. The students' desire to offer therapy was also, in part, confirmed by Hacket et al. (2003).

Some gender differences are also to be found in previous research. Christie (2006) argues in his study that men in feminized organizations have few possibilities to break away from conservative masculinity. Also Kullberg (2011) studies gender differences within the social work profession and finds that Swedish male social workers pursue a horizontal career, which means becoming therapists instead of managers since a therapist is considered to be more highly ranked. This is a change from earlier and might be explained to changes within the social welfare politic; being a manager within public welfare today is a more exposed position than twenty years ago and therefore less coveted.

The basis of student's motivation for social work is often found within their personal experiences, ideological or religious orientation, and traditions within the family (Facchini \& Giraldo, 2013; Osteen, 2011).

\section{Methods}

The present study adopted a quantitative approach, incorporating some qualitative aspects, and investigating the differences in motives and values among social work students $(n=243)$ by means of a questionnaire. Data were collected at four different universities in Sweden during the students' first semester in the autumn of 2010. The universities were Stockholm, Uppsala, Gävle, and Ersta Sköndal. The first two, Uppsala and Stockholm, are large universities in big cities with a classical university milieu. The other two are smaller; Gävle University is starting up a new social work program in a town where academic studies are not so usual, and Ersta Sköndal University, located south of Stockholm and with an outspoken Christian tradition, has a history of social work program spanning decades.

\subsection{Population}

The decision to choose first semester students originated from the assumption that they would not yet be immersed in the norms and the language of the social work discourse. The choice of these four universities was based on a combination of convenience and curiosity. The University of Gävle was chosen because it offers the social work program as a distance course, thereby providing us with an opportunity to investigate whether a distance course would affect the outcome. Stockholm University and Ersta Sköndal have run social work programs for many years. Stockholm University differs from the other universities in the study by having a considerably more extensive program. In Uppsala and Gävle, the programs are quite new.

\subsection{Sample}

The sample comprised 243 first semester social work students, $87 \%$ of whom were females. The over-representation of women was not unusual for these four universities, but is representative of social work courses in Sweden (Amnéus \& Gillström, 2008, Engström, 2004). The mean age of the respondents was 29 years (s.d. = 8). Students reporting parents with only a primary or secondary course as their highest level of completed course comprised $44 \%$ of the participants in the study, while $56 \%$ had at least one parent with a university or college course, confirming a previous study at Stockholm University, where $58 \%$ of the students' parents had finished a tertiary course (Khalaji, 2010). 
Table 1. Sample (question 1, 2 and 10)

\begin{tabular}{|c|c|c|c|c|c|}
\hline & $\begin{array}{l}\text { Numbers of } \\
\text { students } \\
\text { responding }\end{array}$ & $\begin{array}{l}\text { Percentage of } \\
\text { total population }\end{array}$ & $\begin{array}{l}\text { Percentage of } \\
\text { female respondents }\end{array}$ & $\begin{array}{l}\text { Mean age of } \\
\text { respondents }\end{array}$ & SD \\
\hline Gävle & 55 & 78 & 87 & 31 & 9 \\
\hline Sköndal & 56 & 80 & 84 & 30 & 7 \\
\hline Stockholm & 64 & 47 & 86 & 27 & 7 \\
\hline Uppsala & 68 & 97 & 90 & 27 & 7 \\
\hline Total sample & 243 & 70 & 87 & 29 & 8 \\
\hline
\end{tabular}

\subsection{Procedure}

The researchers handed out the questionnaires personally at the end of lectures, and remained in the classroom in order to answer questions from the students. Most of the students completed the questionnaires while in class, but a few filled them out later, returning them at the following session. Students were requested to hand in their completed questionnaires anonymously. The students participated on a voluntary basis, and $70 \%$ of them completed the questionnaire. The large shortfall occurred because most of the students in Stockholm were not present during the researchers' visit ( $47 \%$ of respondents).

\subsection{Questionnaire}

The questionnaire was developed specifically for the study and contained 10 questions. The first two questions covered simple background data: gender and age. The third question asked what the students considered to be the most important purpose of social work. They were allowed to mark a maximum of three alternatives from nine options 1 . This question was used in a previous study by Hackett et al. (2003). The fourth question asked what motives had been important in making the student decide on the course. This question allowed a choice of several alternatives from 16 options2. Question five concerned whether the student might have had a significant role model who influenced the decision to become a social worker. If yes, the student was asked to describe this person (question six). In question seven, students were asked to state how sure or unsure they were that they had chosen the right course. They had four options in their answer to this question (sure, fairly sure, rather unsure, and unsure). In question number eight (also used in a study by Svensson, 2008; 2009) the respondents were asked what personal characteristics they would hope to have in their professional role. They had 20 options (ideal qualities of a professional social worker) and were allowed to choose five. The options were selected as a result of discussions with practitioners, researchers, and teachers within the social work program at Lund University, Sweden, and represented the ideal traits of a social worker (Svensson, 2008)3. Question number 9 was an open-ended one in which students were asked to list their three greatest expectations of the program. Question 10 concerned the course of study of the students' parents.

The optimal format of the questions, open-ended or closed-ended, was considered, taking account of the following. Closed-ended questions would enable a quick and easy analysis of the data. Should the choices offered fail to provide an appropriate set of alternatives this might constitute a problem. On the other hand, giving the respondents unlimited possibilities of expressing themselves in their own words might present another problem; the answers would be very difficult to analyse. Mowbray and Yoshihama (2001) advise that both types of questions should be employed: open-ended, to give the respondents the possibility of expressing themselves in their own way, and closed-ended, since such questions facilitate comparison of the results with results of other studies. Most of the closed questions in this study had been used in previous investigations (Hackett et al., 2003; Svensson, 2008; 2009), which enabled us to compare results, and they were also useful when assembling the questionnaire.

\footnotetext{
1 1) To help people improve their lives, 2) To make sure that vulnerable groups in society receive protection, 3) To evaluate people's needs, 4) To stand up for vulnerable people, 5) To give advice, 6) To give financial support, 7) To offer therapy, 8) To maintain order, 9) To control people's behaviour.

2 1)Wish to change inequalities in society, 2) Wish to be able to give advice and support, 3) Need for a professional role, 4) Need for secure employment and salary, 5) Opportunity to put my religious convictions into practice, 6) Wish for personal development, 7) Commitment to vulnerable, neglected groups in society, 8) Wish to gain knowledge, 9) Career options, 10) Wish to receive respect, 11) Wish to be of importance to others, 12) Aptitude for caring professions, 13) Need of a formal academic degree, 14) Wish to fulfil myself, 15) Interest in social issues, 16) Opportunity to put my political convictions into practice.

3 1) Decisive, 2) Effective, 3) Empathetic, 4) Flexible, 5) Formal, 6) Evidence-based, 7) A good listener, 8) Have power, 9) Competent, 10) Creative, 11) Knowledgeable, 12) Caring, 13) Bureaucratically correct, 14) Independent, 15) Kind, 16) Confident, 17) Clear, 18) Patient, 19) Friendly, 20) Honest.
} 


\subsection{Analyses}

The analysis program SPSS (Version 20 for Windows) was used for processing the collected material. Descriptive statistics were used to process data, i.e. the responses to the questions. Two-step cluster analysis procedure was used to identify different motives (students' answers), clusters based on 17 variables. A chi-square test was used to compare two or more groups and the outcome variable was categorical.

\subsection{Limitations}

Three shortfalls need to be mentioned. Firstly, the present study did not contain any control questions for evaluating reliability, which might be considered an imperfection. However, in the sections with open-ended questions, students provided responses that to some extent supported previous responses since their reactions were congruent with these. Secondly, although the distribution between male and female students in the present study corresponded to national figures, women dominated the sample, making it problematic to draw conclusions about the male respondents. Nevertheless, the differences that are highlighted and discussed in the article are significant. Thirdly, the large shortfall in student responses during the collating of data could be perceived as a problem; however, it happened because most of the students in Stockholm were not present during the researchers' visit (47\% respondents). An average of $85 \%$ of the students at the three other sample locations completed the questionnaire, which suggests the absence of students in Stockholm was probably just an unfortunate coincidence.

\section{Results}

\subsection{Most important aims of social work}

Table 2. What do you consider to be the most important aims of social work? Question 3. (Values in percentages amongst the three most important).

\begin{tabular}{llll}
\hline & Total & Males & Females \\
\hline Help people improve their lives & 93 & 94 & 94 \\
\hline Advocate on people's behalf & 65 & 59 & 66 \\
\hline Ensure that vulnerable people are protected & 63 & 59 & 63 \\
\hline Give people advice & 20 & 31 & 18 \\
\hline Provide assessments of people's needs & 18 & 22 & 17 \\
Offer therapy & 14 & 12 & 13 \\
\hline Provide financial assistance & 9 & 16 & 8 \\
\hline Maintain the status quo in society & 2 & 0 & 2 \\
\hline Control people's behavior & 1 & 0 & 1 \\
\hline
\end{tabular}

When students were asked what they thought social work's three most important aims were, the first one was to "Help people improve their lives". The second and third most important were to "Advocate on people's behalf" and to "Ensure that vulnerable people are protected". Least important was to "Control people's behaviour" and to "Maintain the status quo in society". No gender differences were observed.

\subsection{Students' motivations to choose social work education}

Table 3. What motive/motives have been important when deciding on your education? Question 4. (Values in percent).

\begin{tabular}{|c|c|c|c|c|}
\hline Motives & Total & Males & Females & $\mathrm{p}$ \\
\hline Commitment to vulnerable people & 64 & 50 & 67 & \\
\hline Interest in social issues $* *$ & 64 & 41 & 68 & 0,05 \\
\hline $\begin{array}{l}\text { Able to provide advice and } \\
\text { support* }\end{array}$ & 64 & 47 & 67 & 0,01 \\
\hline Affect inequality & 59 & 56 & 60 & \\
\hline Personal development & 49 & 50 & 48 & \\
\hline Gain knowledge & 41 & 31 & 43 & \\
\hline To be important for others & 24 & 19 & 25 & \\
\hline Talent & 24 & 28 & 23 & \\
\hline
\end{tabular}




\begin{tabular}{lllll}
\hline Safe position & 19 & 28 & 17 & \\
Career opportunities & 17 & 6 & 19 & 0,05 \\
Formal degree** & 16 & 31 & 14 & \\
Professional role & 15 & 19 & 14 & 0,01 \\
Realize myself & 11 & 16 & 11 & \\
Political beliefs* & 4 & 13 & 3 & \\
Get respect & 3 & 3 & 3 & \\
Religious beliefs & 3 & 3 & & \\
\hline $01, *$
\end{tabular}

$* *=p<0.01, *=p<0.05(X 2=7.9, p<0.05$, d.f. $=4$, chi-square test $)$

Four motives dominated among the students: "Commitment to vulnerable people", "Interest in social issues", "To be able to provide advice and support" and "To be able to influence inequality". "Commitment to vulnerable people" $(64 \%)$, "Interest in social issues" (64\%) and "Ability to provide advice and support" (64\%) were, overall, the most chosen variables by both men and women. Also, "To be able to influence inequality" was frequently chosen, and nearly 50 percent of the students chose "Personal development" as an alternative. Forty-one percent of the students chose the variable "Gain knowledge". However, our question number 9, where the students had an opportunity to comment on their expectations of the program, revealed that comments on "Gain knowledge" dominated over comments on "Altruistic motives". The altruistic motives comprised: "To affect inequality", "Religious" and "Political beliefs", and "Having an interest in social issues". All other motives were classified as individualistic. Examples of students' comments are:

\section{To gain knowledge, to feel equipped for work}

To acquire tools for helping/dealing with people in need of help

To gain knowledge

\section{To acquire a solid foundation of knowledge within many different areas}

To deepen knowledge, thereby obtaining a solid foundation for practicing the profession

In terms of students' motivations for choosing courses within social work, the analysis revealed a number of prominent differences between the genders. Female students preferred "Interest in social issues" $(68 \%$ for females and $41 \%$ for men, $\mathrm{p}<0.05$ ) and "Ability to provide advice and support" ( $67 \%$ for females and $47 \%$ for men, $p<0.01)$. Furthermore, another significant difference between the genders was that men gave a higher ranking to motives such as "Formal degree" ( $31 \%$ compared to $14 \%, p=0.05)$ but also to "Political beliefs" $(13 \%$ compared to $3 \%, p=0.01)$. Motives such as "Religious belief" (3\%), "Getting respect" (3\%), and "Political beliefs" $(4 \%)$ were the least chosen motives, considering men and women together.

\subsection{Students' motives split into groups}

Table 4. Results of two-step cluster analysis of students' answers concerning what motive/motives have been important when deciding education. (Values in percent)

\begin{tabular}{|c|c|c|c|}
\hline Two-step cluster & Total (n) & $\begin{array}{l}\text { Individualists } \\
\text { (First cluster) }\end{array}$ & $\begin{array}{l}\text { Altruists } \\
\text { cluster) }\end{array}$ \\
\hline Commitment to vulnerable people & 155 & 45 & 55 \\
\hline Interest in social issues & 155 & 48 & 52 \\
\hline Able to provide advice and support & 154 & 41 & 59 \\
\hline Affect inequality & 143 & 43 & 57 \\
\hline To be important for others & 58 & 41 & 59 \\
\hline Political beliefs & 10 & 20 & 80 \\
\hline Personal development & 117 & 72 & 28 \\
\hline Gain knowledge & 99 & 80 & 20 \\
\hline Talent & 58 & 62 & 38 \\
\hline Safe position & 45 & 76 & 24 \\
\hline
\end{tabular}




\begin{tabular}{lccc}
\hline Formal degree & 45 & 78 & 22 \\
Career opportunities & 42 & 95 & 5 \\
Professional role & 36 & 69 & 31 \\
Realize myself & 27 & 59 & 41 \\
Get respect & 8 & 75 & 25 \\
Religious beliefs & 8 & 50 & 50
\end{tabular}

The two-step cluster analysis procedure was used to identify different motive clusters based on 16 variables.

Two major groups were observed amongst the students. The first group were described as driven by individualistic motives, since they showed a greater preference for alternatives such as: "career opportunities" (95\%), "personal development" (72\%), "to realize myself" (59\%), "getting respect" (75\%), and to get a "secure position" (76\%). The students described here as individualists also had a preference for variables such as "gain knowledge" (80\%) and "desire to have a formal degree" (78\%). The second group, the altruists (cluster 2, 42\%), chose variables such as: "political beliefs" ( $80 \%$ of all answers for this question), "affect inequality" (57\%), "commitment to vulnerable people" $(55 \%)$, and "interest in social issues" (52\%).

\subsection{The Professional Role}

Table 5. How would you like to be seen in your professional role? Question 8. (Values in percent).

\begin{tabular}{|c|c|c|c|c|}
\hline Professional Role & Total & Males & Females & $\mathrm{p}$ \\
\hline Empathetic & 71 & 73 & 71 & \\
\hline Competent & 66 & 67 & 66 & \\
\hline A good listener & 58 & 57 & 59 & \\
\hline Knowledgeable* & 44 & 27 & 47 & 0,01 \\
\hline Flexible* & 39 & 50 & 37 & 0,01 \\
\hline Honest* & 34 & 43 & 33 & 0,01 \\
\hline Clear & 32 & 27 & 33 & \\
\hline Creative & 30 & 33 & 29 & \\
\hline Patient & 28 & 20 & 29 & \\
\hline Caring & 20 & 23 & 20 & \\
\hline Independent* & 20 & 10 & 21 & 0,01 \\
\hline Effective & 18 & 17 & 18 & \\
\hline Confident & 17 & 10 & 18 & \\
\hline Decisive & 12 & 7 & 13 & \\
\hline Evidence-based & 7 & 7 & 8 & \\
\hline Friendly* & 6 & 13 & 5 & 0,01 \\
\hline Having power & 2 & 3 & 2 & \\
\hline Kind & 2 & 3 & 2 & \\
\hline Bureaucratically correct & 1 & 0 & 1 & \\
\hline Formal & 0 & 0 & 0 & \\
\hline
\end{tabular}

$* *=p<0.01,{ }^{*}=\mathrm{p}<0.05(\mathrm{X} 2=7.9, \mathrm{p}<0.05$, d.f. $=4$, chi-square test $)$

Three professional characteristics stood out among the Swedish students in the present study, namely "Empathetic", "Competent", and to be "A good listener" (table 5 and chosen by $71 \%$ - for "empathetic", $66 \%$ - for "competent", and $58 \%$ for a good listener. Figures from total). Although some of the questionnaire alternatives were similar, the values of the options differed, and since students were allowed to choose only three alternatives, they obviously rated some as more important than others. The concept "Kind" (2\%) appeared to be less attractive than "Friendly" (6\%), and "Competent" (66\%) was more attractive compared to "Knowledgeable" (44\%), although "Knowledgeable" was chosen 
a fairly large number of times. A difference between genders that was of particular interest (since the proportion of men in the study was so low) was that more men than women chose "Friendly" $(13 \%$ compared to $5 \%, p=0.01)$ and "Flexible" ( $50 \%$ compared to $37 \%, \mathrm{p}=0.01)$. Other noteworthy gender differences were women choosing the attributes "Knowledgeable" ( $47 \%$ compared to $27 \%, p=0.01)$, and "Independent" $(21 \%$ compared to $10 \%, p=0.01)$ to a larger extent than men (see table 5). Only 7\% of the students wished to be "Evidence-based". Few students responded that they would like "To have power" $(2 \%)$. It is possible, however, that students misinterpreted the intention of this option, relating it to dominance over clients or users, rather than having leverage when dealing with authorities and institutions.

\subsection{Role models}

Of 237 respondents, 159 answered they did not have any specific role model that had encouraged them to go into social work (question 5). Seventy-eight answered they had, and of those, 34 gave different professionals as their inspiration. These role models were not only different kinds of social workers but could also be teachers, priests, counsellors or therapists. Thirty-three of these professionals were positive role models. One was an example the student wanted to avoid; the student wanted to be a better social worker compared to the one he had met. Twenty-nine of the role models were family members, most often a mother or father but could also be others. Ten of the students stated friends as role models. Six of the students gave examples that were not personally known to them; Jesus, Mother Theresa, Shane Clariborne, Dorothy Day, and Fadime, a young Kurdish girl who fought for women's' rights but was killed by her family because she did not live according to the norms of her Kurdish family (question 6). Of the total student group 94 percent were very sure or quite sure they chosen the best education for themselves ( 58 percent very sure, 36 quite sure). Six percent were unsure or very unsure (question 7).

\section{Discussion}

\subsection{Tomorrow's social worker}

So, what has the study taught us about the social work of tomorrow? We found that when students answered the question on what motives had influenced their decision to study social work, altruistic motives dominated, as also found in several other studies about social work students (Facchini \& Giraldo, 2013; Osteen, 2011; Hackett, 2003; Kuronen, Matthies \& Kresal 2003; Giurgiu \& Marica, 2013; Steven et al. 2010; Bradley et al, 2013). However, when they answered the open question on what expectations they had of the program, the focus of the answers was on learning things and acquiring knowledge. Some motives, classified as altruistic, appeared in answers to this open-ended question, but the majority were concerned with knowledge. There is a possibility that the students answered the fixed questions in a politically correct manner, in the way they thought was expected of them as future social workers. Fram and Miller-Cribbs (2008) discuss the perceptions of "liberal bias" in social work programs and the difficulty of creating an open climate where it is acceptable to discuss all sorts of opinions among the social work students. Having said this, it is interesting to consider what happened in the cluster analysis. Two groups were discerned, which were quite evenly divided (42\% and 58\%). The larger group was the individualistic group and the smaller the altruistic. Actually, as Stevens et al. (2010) state, students and social workers can be both altruistic as well as individualistic. However, in this study, it seems as if students were a little more individualistic when they had to choose one or the other. The role models given by the students give some idea about the basis of their motivation and are in agreement with earlier research by Facchini \& Giraldo (2013) and Osteen (2011). When it came to stating what the most important task of social work was, it seems that the Swedish student group was not very different from other social work students in Europe (Hackett et al, 2003). In fact, both the English and Finnish sample had the same three tasks as the Swedish students, and the Slovenian and students from former East Germany were not very different either. The only way in which the Swedish sample stood out was that they, to a lesser degree, endorsed "assessment of people's needs" as a specific social work task.

\subsection{Differences depending on gender}

When students answered what motives had been important when deciding on their education, four significant gender differences appeared. Female respondents were vaguer about their motives, confirming they were "interested in social issues" and that another motive for choosing the profession was that they would be "able to provide advice and support". Male respondents on the other hand stated motives such as getting a "formal degree" as well as "political beliefs". These statements are closer to traditional gender roles; however, the students' answers were not consistent with the answers to the question about characteristics they aspired to have as professionals. Here, male respondents chose traditionally female characteristics - friendly and flexible - when they described how they would like to be. Might the choice of these traits perhaps be a manifestation of men's aspiration to adopt the norms they presume a social worker is expected to follow? It is not easy to work as part of the male minority in a feminized profession, as Christie (2006) argues. However, it may well be of interest to further investigate whether this was a conscious adaption from the male students, or whether the choices can be attributed to an actual difference in value perspectives between the genders. 
Also, this result is contradictory to Christie's (ibid) who claimed that male social workers are often forced into performances of masculinity. According to Christie, male social workers are perceived as different from women, but also different from other men. It was interesting in this study that female respondents also chose traditionally male attributes to a larger extent than the male respondents - at least when it came to being "knowledgeable" and "independent". These expressions might be indications of gender roles becoming more equal, or are they only an expression of students' political correctness?

\section{Conclusions}

To conclude, the study has not being able to identify any future changes in social work, that are likely to be prompted by the current generation of trainee social workers. Newly graduated social workers are probably able to affect social work; however, this study reveals they will not, since there are no motives that are different to earlier ones. In some way this could be interpreted as showing that social work has basic values that are constant over time and cultures.

\section{References}

Amnéus, I., \& Gillström, P. (2008). Vilka är studenterna? En undersökning av studenterna i Sverige. Rapport 33. Högskoleverket: Stockholm.

Bradley, C., Maschi, T., O’Brien, H., Morgen, K., \& Ward, K. (2012). Faithful but different: Clinical Social Workers Speak about Career Motivation and Professional Values. Journal of Social Work Education, 48(3), 459-477. http://dx.doi.org/10.5175/JSWE.2012.201000043

Christie, A. (2006). Negotiating the uncomfortable intersections between gender and professional identities in social work. Critical Social Policy, 26(2), 390 - 411. http://dx.doi.org/10.1177/0261018306062591

Christie, A., \& Kruk, E. (1998). Choosing to become a social worker: Motives, incentives, concerns and disincentives. Social Work Education, 17(1), 21- 34. http://dx.doi.org/10.1080/02615479811220031

Crisp, B. R. (2012). Helping others or a rewarding career? Investigating student motivations to train as social workers in England. Journal of Social Work, 12(1), 16-36. http://dx.doi.org/10.1177/1468017310380085

D’Aprix, A., Dunlap, K., Abel, E., \& Edwards, R. (2004). Goodness of Fit: Career Goals of MSW Students and the Aims of the Social Work Profession in the United States. Social Work Education, 23(3), 265-280. http://dx.doi.org/10.1080/0261547042000224029

Dellgran, P., \& Höjer, S. (2005). Attitudes and motives among Swedish social workers. European Journal of Social Work, 8(1), 39-62. http://dx.doi.org/10.1080/136914504200033136

Engström, J. Å. (2004). Statistik och analys. Högskoleverket. National agency for higher Education. (Electronic) Retrieved the 3rd of April 2012:http://www.hsv.se/download/18.539a949110f3d5914ec800075687/040129.pdf

Facchini, C., \& Giraldo, S. (2013). The University Training of Social Workers: Elements of Innovation, Positive and Critical Aspects in the Case of Italy. British Journal of Social Work, 43, 667-684. http://dx.doi.org/10.1093/bjsw/bcs002

Fortunato, V., Dellgran, P., \& Höjer, S. (2007). Exploring the future of social work. Motives and attitudes among Italian and Swedish social work students. In E. Frost, J. Maris \& A. Campanini (Eds.), Social Work Education in Europe, 149-166. Rom: Carocci Editore.

Fram, S. M., \& Miller-Cribbs, J. (2008). Liberal and conservative in social work education: exploring student experiences. Social Work Education, 27(8), 883-897. http://dx.doi.org/10.1080/02615470701844266

Giurgiu, L., \& Marica, M. (2013). Professional Values in Social Work Students and Mid-career Practitioners: A Comparative Study. 5th International Conference EDU-WORLD 2012 - Education Facing Contemporary World Issues.

Hackett, S., Kuronen, M., Matthies, A-L., \& Kresal, B. (2003). The motivation, professional development and identity of social work students in four European countries. European Journal of Social Work, 6(2), 163-178. http://dx.doi.org/10.1080/1369145032000144421

Khalaji, F. (2010). Kartläggning av studentpopulationen vid Stockholms universitet, avseende födelseregion, föräldrarnas utbildningsnivå samt gymnasieövergång. Rapport. Studentavdelningen: Stockholms universitet.

Kullberg, K. (2011). Socionomkarriärer. Om vägar genom yrkeslivet i en av välfärdsstatens nya professioner. (Ph.D. thesis). Goteborg University. Department for social work.

Mowbray, C. T., \& Yoshihama, M. (2001). Surveys in: B. Thyer (Ed.) The handbook of social work research methods. 
Thousand Oaks: Sage.

Osteen, P. J. (2011). Motivations, values, and conflict resolution: students' integration of personal and professional identities. Journal of Social Work Education, 47(3), 423-444. http://dx.doi.org/10.5175/JSWE.2011.200900131

Oyston, E. (2003). Centered on learning: Academic case studies on learning center development. Aldershot. Ashgate.

Payne, M. (1999). The moral base of social work. European Journal of Social Work, 2(3), $247-258$. http://dx.doi.org/10.1080/13691459908412193

Perry, R. (2003). Who Wants to Work With the Poor and Homeless? Journal of Social Work Education, 39(2), $321-341$. http://dx.doi.org/10.1080/10437797.2003.10779138

Stoesz, D., Karger, H., \& Carrilio, T. (2010). Social Work Education as Reactionary Tribalism: An Essay Review of a Dream Deferred: How Social Work Education Lost Its Way and What Can be Done. New Brunswick, NJ: Aldine Transaction.

Svensson, K. (2008). Socionomer och socialt arbete. En enkätstudie av ett professionellt fält. Meddelandeserien, Socialhögskolan. Lunds universitet: Lund.

Svensson, K. (2009). Identity Work through Support and Control. Ethics and Social Welfare, 3(3), $234-248$. http://dx.doi.org/10.1080/17496530903209410

Urbonienè, A. (2005). Assumptions for Improving Social Work Education: a Comparative Approach. Social Sciences, 1(47), 33-40.

\section{(cc) EY}

This work is licensed under a Creative Commons Attribution 3.0 License. 